\title{
Understanding Omnichannel Behavior:
}

Focus on Communication Channels and Engagement

\section{オムニチャネル時代における消費者行動の基本理解}

\section{ーコミュニケーションチャネル利用とエンゲージメント行動に焦点を当てて 一}

\author{
Ushio Dazai ${ }^{* 1}$, Akihiro Nishihara ${ }^{* 2}$, Takashi Okutani ${ }^{* 3}$, Hiroyuki Tsurumi ${ }^{* 4}$ \\ 福岡大学 商学部 准教授 \\ 太宰 潮 \\ 一橋大学大学院 経営管理研究科 \\ 奥谷 孝司 \\ 亜細亜大学 経営学部 准教授 \\ 西原 彰宏 \\ 横浜国立大学大学院 国際社会科学研究院 教授 \\ 鶴見 裕之
}

\footnotetext{
${ }^{* 1}$ Associate Professor, Faculty of Commerce, Fukuoka University, Japan, udazai@fukuoka-u.ac.jp

${ }^{* 2}$ Associate Professor, Faculty of Business Administration, Asia University, Japan, nakihiro@asia-u.ac.jp

${ }^{* 3}$ Hitotsubashi Business School, School of Business Administration, Hitotsubashi University, Japan, cd171005@g.hit-u.ac.jp

${ }^{*}$ Professor, Faculty of International Social Sciences, Yokohama National University, Japan, tsurumi@ynu.ac.jp
}

\begin{abstract}
In this paper, we applied several findings from multichannel research to understand customer-engagement behaviors, such as app use in an omnichannel environment, and explored the relationship between these behaviors and customer or retailer evaluations. Our research indicated that showrooming or webrooming enhances the reputation and engagement of companies implementing an omnichannel strategy. Especially, engagement behaviors correlated strongly with customer evaluations such as RFM. Also, a customer who showed a high level of engagement was more likely to visit a store, resulting in increased sales. Furthermore, our results show that use of multiple communication channels creates a synergistic effect on store visits. Finally, our analysis of outside channels, which are not controlled by the company, showed the presence of customers who intensively used other companies' apps for earning points, before and after use of the company's channel primarily for the purpose of earning points.
\end{abstract}

Keyword : Omnichannel retailing, Multichannel retailing, Customer engagement, Marketing communication

要約 : 小売業にオムニチャネルという言葉が登場して 10 年近くが経ち, その間小売業がインターネットやモバイルデバイス上 のアプリなどを介してマーケティングを行うことは一般的なものとなった。しかし, デバイスや通信方法がいかに進化しようと も, 自社が管理もしくはアプローチ可能なチャネルを介して顧客とやり取りをするという基本は変わらない。本論では, オム二 チャネル環境下において, アプリ利用などのエンゲージメント行動の理解促進を目的とし, マルチチャネル研究の知見を応用す ることで, 小売業の評価や既存の顧客指標との関連を探索した。その結果, ショールーミングなどの経験がオムニチャネル戦略 を行う企業の評価を高めること, エンゲージメント行動は RFM などの既存指標と強く相関をするが, 売上増の要因となるのは 来店頻度がより高まることにあること, 複数のコミュニケーションチャネルを利用することで, 来店に相乗効果が生まれること などを示した。また自社保有チャネル外の分析例からは，小売業のアプリ利用の前後に，ポイント獲得が主目的と考えられる他 社アプリを集中的に使うセグメントの存在などを示し，エンゲージメント行動を行う顧客の多角的な理解を進めた。

キーワード : オムニチャネル, マルチチャネル, エンゲージメント, マーケティングコミュニケーション

Information : Received 18 June 2020; Accepted 25 June 2020 


\section{I. はじめに}

スマートフォンを中心としたモバイルデバイスやアド テクノロジーの普及, そしてコロナウイルス感染拡大に 伴い, 消費者がいつでもどこでも，もしくは自宅に居な がらにして情報収集や購入，そして受取りなどを行える 環境作り，すなわちオムニチャネル環境の整備が小売業 を中心に進んでいる。

オムニチャネル化が進行することによって消費者行動 はもちろん, 消費者とのコミュニケーションもより複雑・ 多様化しているが, 現在はあらゆるチャネルにおける顧 客経験をカスタマージャーニーという時間軸で捉え， 「絆」もしくはネット上の反応などと捉えられるエンゲー ジメントの獲得や醸成を目指すことが議論されている。 しかし, オムニチャネル時代おける消費者の多様な行動 やエンゲージメントがどのように既存の成果に影響する のか, 自社管理の外にあるチャネル利用はどのように影 響するのか, といった基本的なリサーチ・クエスチョン にはコンセンサスが得られていないのが現状である。

本研究は主に小売業を対象として，オムニチャネル時 代における消費者による特徵的な行動と, エンゲージメ ント行動に焦点を当て, これらの行動について検討する と共に, 仮説検証型ではなく探索的なアプローチから, アンケート結果, 企業のデータ, そして消費者シングル ソースデータという多様なデー夕に基づきながら，上記 のリサーチ・クエスチョンに答えを出してゆく。

\section{II. 現状・レビュー}

\section{1. 社会背景・現状}

オムニチャネル時代においては，これまで消費者側が 組み合わせていたチャネルの横断的な利用から, 企業側 がチャネル間の行き来を促すことで，ショールーミング やWEB ルーミングといった行動が当然のように見られ るようになった。また，マーケティングや顧客の文脈で 語られるエンゲージメントは, 実務においては, WEB サ イトやソーシャルメディア, もしくはモバイルアプリケー
ション（以下アプリ）上における企業側のコミュニケー ション施策に対する消費者の反応（「いいね」を押す，リ プライ・リッイートをする等）として捉えられることが 多い。本節ではこれらの行動が起こるWEB サイトやア プリもチャネルのひとつという観点から，オムニチャネ ルという言葉をまず振り返ってゆく。

オムニチャネルという言葉は米国を中心に 2010 年頃 から広がっていった。その背景や初期における変遷は Yamamoto（2015）などに詳しいが, 日本では 2013 年後 半に大きく話題が広がり, 2015 年にセブン \&アイグルー プがスタートさせた「Omni7 (オムニセブン)」が注目を 集め, 日本における小売流通専門誌や書籍でも同年から この言葉が多く登場している。オムニチャネルという言 葉の定義としては, Kakui（2015）や Okutani（2016）な どでも議論があるが，本論では Kondo（2015, 2018）に よる「すべてのチャネルを統合し, 消費者にシームレス なショッピング経験を提供する顧客戦略」を用いる。

2018 年の米国におけるレポート「MCM Outlook Survey 2018」(Multichannel Merchant, 2018）によれば,「自社の オムニチャネル・ビジネスは利益を生む」と回答した企 業は, 2016 年の $45 \%$ から 2017 年には $58 \%$ と多数派と なった（Garcia, 2018, p. 8)。これらの数字からは，才ム ニチャネル環境の整備は企業の業績に貢献する段階に 入った，と言えるだろう。

企業事例としては既に数多くのケースが紹介されてい るが, 無印良品やカメラのキタムラなどをはじめとした 多くの企業が, 実店舗への来店, WEB サイト訪問, EC サイトにおける購入, スマートフォンによるアプリ利用, SNS 利用，イベントへの参加などを連動させていること などが, 雑誌記事や書籍などで語られている。

その中でも，アプリやWEB サイトなどを通じて顧客 とコミュニケーションを行うことや，実店舗のみならず ECサイトや他のチャネルにおける顧客との接点や顧客 の行動を知ることが重要であると指摘されている。先に 挙げた企業の例では, 実店舗と EC サイトの双方の成果 を掴むための「EC 関与売上」1)による評価といった社内 的な対応が組織運営に効果的とされる。その他にもアプ リ利用者の客単価が倍になる, 実店舗への来店客数が増 加する, WEB サイトやアプリを通じて商品に対してお気 
に入り登録など何らかの行動を起こした顧客の 4 割超が 来店し， 3 割程度は実際に購入を行う，といった事例が 報告されている。こうした企業の事例からは，成果測定 指標の作成や在庫情報などの経営側の情報を統率するこ とも含め, 顧客戦略としてだけでなく, 経営戦略全体と してオムニチャネルを多角的に捉える必要性があること がわかる。

しかし一方で, 複数のチャネルがシームレスに連携す ることの難しさと, 顧客の行動を把握できる範囲が Lemon and Verhoef（2016）が顧客経験を捉える枠組みと して提示する中の, 自社の管理が可能な「ブランド・オ ウンド」タッチポイント ${ }^{2) に}$ ウ限られている様子も散見さ れた。

筆者らによる国内アパレル企業へのヒアリングからは 「チャネル統合はまず自社チャネルが最優先」という意見 を聞くことができたが，成功事例として取り上げられる ケースであっても，まずは自社チャネルが管理や分析の 対象であり，自社の管轄外を含む複雑なチャネル統合や そのチャネルにおける消費者の分析は思うように進んで いないことがわかった。IT 基盤をべースとするチャネル 統合の難しさは，各業界を代表する企業 352 社による調 査であっても，「販売チャネルでシームレス且つ一貫した 経験を提供できている」という項目に回答をした企業は 25\%という数字の低さに表れている（Garcia, 2018, p. 10, 元出典: Brightpearl and Multichannel Merchant, 2017)。 そのため, シームレスなショッピング経験をもたらすチャ ネル統合や，自社内外のチャネルを介して行われる消費 者による行動，そしてエンゲージメント行動に焦点を当 てることには意義が見出せる。

\section{2. オムニチャネル研究について}

インターネットが登場する以前の比較的早期からダイ レクトマーケティングの分野で，コールセンター，カタ ログ，ダイレクトメールなどの各チャネルにおける購入 などが語られてきた (Rudy, 1985 等)。インターネットの 登場以降の議論としては,「クリック・アンド・モルタ ル」（Gulati \& Garino, 2000 等）のテーマからはじまり, マルチチャネル研究, クロスチャネル研究から, ショールーミング (Rapp, Baker, Bachrach, Ogilvie, \&
Beitelspacher, 2015）などを含むオムニチャネル研究へと いう流れがあり（Verhoef, Kannan, \& Inman, 2015)，「マ ルチチャネル・ショッパー」(Kumar \& Venkatesan, 2005) などの研究テーマも存在する。

先の Kondo $(2015,2018)$ や, 顧客管理の視点から包 括的なレビューを行った Osera（2015）のまとめによる と, オムニチャネル研究におけるひとつのテーマに「複 数チャネルを利用する顧客の優良性」がある。このテー マに取り組んだ研究としては Blattberg, Kim, and Neslin （2008）や Neslin et al.（2006），国内で非常に参考になる 研究としては Matsuda（2017）などがあるが，基本的に はより多くのチャネルを利用して購入を行った顧客は優 良性が高いことが知られている。Matsuda（2017）は実 データの詳細分析から, 優良性が高まるのは 1 回当たり の購入個数や, 1 回当たりの購入金額, 1 点当たりの金 額でもなく, 来店回数が増えることがマルチチャネル顧 客の優良性の要因であると指摘している。

しかしこれらの既存研究においては, オンラインとオ フライン (う実店舗 $)$ の両チャネルや複数のチャネルを 「販売チャネル」として捉えていることが多く，購入外の 行動についての知見がまだ不足していることが指摘でき る。オムニチャネル時代には，チャネルは，販売チャネ ルのみならず, コミュニケーションチャネルでもあり， これらを明確に識別することが難しくなっている。スマー トフォンやアプリのようなデバイス・ツールや SNS など を含む多様なタッチポイントにおける何らかの反応や， 購入前後における複雑な顧客経験もしくはカスタマー ジャーニーの理解, そして顧客エンゲージメントのマネ ジメント等が語られることからも, チャネルを購入・販 売にのみ限定する時代は終わったと言える。従って, 企 業は今後, 販売チャネルに加え, コミュニケーションチャ ネルとしてオムニチャネルを捉え，そのチャネルにおけ る行動を分析してゆくことが求められる。

またエンゲージメントという言葉については, 組織心 理学や教育心理学, 広告論や消費者行動研究などにおい て注目を集める概念であり，マーケティングにおいては， 先述した企業によるソーシャルメディア上の投稿に対す る消費者の「いいね」を押すなどの行動として捉えられ るメディア・エンゲージメントもあるが, 本論では「顧 
客エンゲージメント」を議論の対象とする。

Nishihara（2019）は, 顧客エンゲージメントはその行 動面と心理面の両面から捉えられるべきと述べているが, 本論では行動面に主な焦点を当てる。購入以外の行動面 においては先に挙げた例のほかに，オンラインでは当該 企業に関わるクチコミや写真ないし動画の投稿, アンケー トへの回答，他者の投稿へのコメントなどがあり，オフ ラインにおける行動では, キャンペーン・イベントへの 参加といった行動や家族や友人などへの推奨などが挙げ られている。

小売企業はオムニチャネル戦略を通じて, 自社内外の コントロールの程度が異なるチャネルやコントロール外 のチャネルを連携させることで, 顧客との接点と統合的 な顧客経験のマネジメントを行っていくことが重要であ る。前節の議論を含めると, エンゲージメントにおいて も自社が管理可能なチャネル以外を含めた顧客理解が求 められることになり，そのためにもオムニチャネル環境 下における消費者行動の基礎的な知見を得ることが欠か せないと考えられる。

以上の現状と先行研究から, 大きく次の 2 点がオムニ チャネルにおける顧客理解の課題として指摘できる。1 つ目の課題は, 自社がマネジメント可能な自社チャネル の範疇外の行動把握例が少ないこと。2つ目の課題は, 購入を必ずしも伴わない, コミュニケーションチャネル を介して表出する行動面のエンゲージメントの知見が不 足しており，既存の購入に関わる指標とどのような関係 にあり，既存の知見がどのように応用できるのか，など の研究例が不足していることである。

本論ではこの 2 つ課題を踏まえ，また冒頭で記し た，オムニチャネル時代における多様な行動やエンゲー ジメントがどのように既存の成果に影響するのか, 自社 管理の外にあるチャネル利用はどのように影響するのか, というリサーチ・クエスチョンを踏まえ，大きく 3 つの 調査結果を提示する。まず実証の 1 つ目として，アン ケートデータをもとにオムニチャネル時代の消費者行動 の概要を把握する。実証 1 では特に，ショールーミング と WEB ルーミングというオムニチャネルにおける象徵 的な行動に焦点を当て，消費者によるこれらの行動が企 業評価に繋がっているかを示す。次に実証の 2 つ目とし
てオムニチャネルを展開する企業の顧客データから，エ ンゲージメント行動と既存の購入に関わる指標との関連 を示すと共に, 販売チャネルに関わる既存研究の知見を コミュニケーションチャネルに対して応用することを試 みる。そして実証の 3 つ目として, 調査会社が保有する シングルソースデータをもとにした, 自社の管理範疇外 のチャネル利用によって明らかになった顧客行動の例を 示す。

以降では 3 つの実証結果を章に分けて説明してゆく。

\section{III. 実証 1 : オムニチャネル時代の消費者行動把握 と企業への影響}

本節ではアンケートデータから, オムニチャネル時代 の消費者行動の概要把握を, 特にショールーミングと WEB ルーミングに焦点を当てて示す。またそれらの行動 が企業評価に繋がっているかを確認する。

調査は, オムニチャネル環境下において特徵的な消費 者行動把握と企業への影響確認を目的として, 2017 年 7 月に日本マーケティング学会・オムニチャネル研究会が 実施した。留置調査法によって収集され, 対象エリアと 被験者は首都圈 $30 \mathrm{~km}$ 圈, 15-65 歳の男女, 750 人（男 女比：男 $51.3 \%$, 女 $48.7 \%$, 年代比 : 10 代 $6.4 \%, 20$ 代 $17.5 \% ， 30$ 代 $21.5 \% ， 40$ 代 $26.8 \% ， 50$ 代 $17.7 \% ， 60$ 代 以上 $10.1 \%$ ）となっている。

まずオムニチャネル環境下における行動として, ショー ルーミングと WEB ルーミングの経験者についての情報 を記す。ショールーミングの有無を尋ねたところ，200 人，割合にして $26.7 \%$ が経験者であった。対比されるこ との多いWEB ルーミングの有無を尋ねたところでは, 経験者は 148 人 $(19.7 \%$ ）という結果となった。なお， ショールーミングはスマートフォンの利用時間と大きく 相関し, 平日の利用時間が 1 時間程度だと経験者率は $20 \%$ 程度であったものが，4 時間以上になると, 倍以上 の 40\%ほどとなること，50-60 代は経験者人数が少なく なるが 30-40 代では 20 代に比べて経験者人数は大きく 減らないことを付記しておく。

この数字を他の調査データと比較してみると, 例えば 
クロス・マーケティング社が行った調査 (Cross Marketing Inc., 2014）では, ショールーミング経験者は $16 \%$ となっ ており，時間経過増を踏まえても妥当なところではない かと思われる。しかし，日本通信販売協会（JADMA）が 2015 年に行った調査「リアル店舗 vs ネット通販」では, 家電購入におけるショールーミング経験者は $60.1 \%$ と なっており, カテゴリーによって大きく数字が変わるこ とは注意をすべきである。検索に関わる行動が具体的な 商品購入に影響することは, 実証の 3 つ目でも紹介を する。

次に, ショールーミングやWEB ルーミングが，その 戦略を実践している企業への評価などにどう繋がってい るかの把握を行う。本調査では実店舗を全国展開してお り，ECやアプリなどの多様なチャネルを保有している 小売業 $\mathrm{A}$ 社（以下 $\mathrm{A}$ 社と表記）を取り上げた。被験者に は実際の企業名を示している。

まず，Kotler, Kartajaya, and Setiawan（2016）が，意思 決定モデル「5A モデル」の最終段階に「Advocacy（推 奨）」を示していることや, Lemon and Verhoef（2016） も目的変数として注目をしている他者推奨 (NPS; Net Promoter Score）を参考にし，ショールーミング・WEB ルーミングとの関連を確認した。またここでは，A 社を 他の人に薦めたいと思うかの有無と，各チャネルの利用 を確認する。

$\mathrm{A}$ 社を他者に推奨する意図があるのは 750 人中 113 人 （15.1\%）であった。実店舗，ECサイト，アプリという チャネル利用経験ごとに他者推奨意向がある消費者の比 率を確認すると，A 社の実店舗での購入経験がある 480
人中では 96 人 $(20.0 \%), \mathrm{A}$ 社の $\mathrm{EC}$ での購入経験があ る 49 人中では 17 人 $(34.7 \%), \mathrm{A}$ 社アプリの利用経験が ある 68 人中では 29 人 $(42.6 \%)$ と, それぞれ他者推奨 比率が高まる結果となり，ECでの購入経験とアプリ利 用の双方がある 18 人中では 10 人 $(55.6 \%)$ に他者推奨 意向が確認された。

ここから，実店舗，ECサイト，アプリともに，各チャ ネルを利用しているほど，また利用するチャネルが多い ほど，他者推奨が高まることが確認できる。A 社に対す る関与が高いと思われる顧客としては当然のこととも考 えられるが, オムニチャネル戦略の実践と, 他者推奨と いう企業の評価については一定の関係があることがわ かった。

次に, A 社に限らないショールーミングや WEB ルー ミング経験の有無と，A 社に対する行動や意識の関連を 表 1 に示す。 $\mathrm{A}$ 社に限らない一般的なショールーミング と WEB ルーミング経験の有無で 4 群（両方有 $=74$ 人, ショールーミングのみ有 $=126$ 人, WEB ルーミングのみ 有 $=74$ 人, 両方無し $=476$ 人）を切り， $\mathrm{A}$ 社への行動と 意識（よく知っている，好きだ，利用できなくなったら 不安，等）の差を確認した。「両方無し」の群が多いこと に注意されたい。表 1 に示す結果の通り，ショールーミ ングと WEB ルーミングの 2 つの行動経験があると， A 社の行動面（実店舗利用, EC サイト利用, アプリでの 各種操作）が向上することに対して，F 值による統計的 有意差が確認できた。一方で，意識面までは明確な差を もたらしていない結果となったが, オムニチャネル環境 下におけるショールーミングおよび WEB ルーミングを

ショールーミング・WEB ルーミング経験者と A 社の行動・意識

\begin{tabular}{ccccccc} 
& 両方有 & WRのみ有 & SRのみ有 & 両方無し & $\mathrm{F}(3,746)$ & $\mathrm{p}$ \\
\hline A 社実店舗購入経験率 & 0.824 & 0.743 & 0.659 & 0.59 & 6.681 & ${ }^{* * *}$ \\
$\mathrm{~A}$ 社 EC サイト閲覧経験率 & 0.419 & 0.27 & 0.27 & 0.132 & 14.862 & ${ }^{* * *}$ \\
$\mathrm{~A}$ 社 ECサイト購入経験率 & 0.122 & 0.027 & 0.087 & 0.057 & 2.407 & ${ }^{*}$ \\
A 社アプリ認知 & 0.243 & 0.203 & 0.167 & 0.122 & 3.335 & ${ }^{* *}$ \\
A 社アプリ購入経験 & 0.095 & 0.027 & 0.048 & 0.029 & 2.635 & ${ }^{* *}$ \\
「A 社をよく知っている」とした人の比率 & 0.122 & 0.095 & 0.103 & 0.065 & 1.436 & n.s. \\
「A 社のことが好きだ」とした人の比率 & 0.459 & 0.608 & 0.46 & 0.46 & 1.959 & n.s.
\end{tabular}

$(\mathrm{SR}=$ ショールーミング, WR = WEB ルーミングの略。*: $\mathrm{p}<0.1$, **: $\mathrm{p}<0.05$, ***: $\mathrm{p}<0.01)$ 
行ったという経験と、オムニチャネル戦略を実践してい る企業への消費者の行動が確認できたことは，今後企業 がオムニチャネル化を推し進める際の効果を示す根拠の 1つとなるだろう。

表 1 に扔いて，ショールーミングやWEB ルーミング 経験の有無により $\mathrm{A}$ 社への評価のうちの認知と選好に対 して差が出なかった理由としては，A 社が比較的安価な 商品も取り扱っていることや，A 社ではなく一般的な ショールーミングや WEB ルーミングとして確認したこ とが原因として考えられる。

\section{IV. 実証 2 : エンゲージメント行動と既存指標・ 既存知見との関連}

\section{1. エンゲージメント行動と既存指標との関連}

本節では，コミュニケーションチャネルにおけるエン ゲージメント行動の基本的な構造や既存の指標との関連 を論じる。次節においては，購買チャネルを前提とした マルチチャネル研究に打いて明らかになっている知見が オムニチャネルにも応用できるかを，小売業の顧客行動 データから探索する。

本節で用いるデー夕は，国内に実店舗を展開し，EC を含むWEB サイト，アプリなど複数のチャネルを有し た小売業の顧客の行動データである。

2015 年以降の約 2 年間, 当該小売業にユーザー登録を して ID が判別できる 5 万人の行動デー夕を対象とする。 直接的な購買以外のエンゲージメント行動として, WEB アクセス回数（ただし PC やモバイルなどデバイスの違
いは考虑していない)，購入日におけるアプリ起動回数， アプリで行える実店舗への物理的な来店もしくは近接回 数（「来店スタンプ」機能や，「チェックイン」機能など で実装されていることが多い)，ECサイト注文の店頭受 取回数の 4 変数を取り上げる。

これらを直接的な購買外の行動としてエンゲージメン 卜行動とみなし，広く用いられている RFM 分析から Monetary（購入金額）と Frequency（来店回数）との関 連を確認したものが表 2 である。各回数や金額はそれぞ れの Monetary の 5 分位に属する顧客が占める比率とし ている。

表 2 の結果から, チャネルに関わるエンゲージメント 行動と Monetary，それに Frequency が強く関連すること が確認できる。相関係数も各チャネル利用と Monetary は有意な相関が確認されている。直接の購入につながら ないアプリの来店・近接機能の利用なども，売上などと 強く関連をしていることが確認され，エンゲージメント 行動は購入金額や来店回数という既存の購入に関わる指 標と強く相関することが確認された。

この結果は非常に単純であり，想定されるレベルかも しれないが，ここで注目したいのが「インセンティブを 伴う行動」である。アプリ利用に何らかのインセンティ ブを設け，顧客の行動を促すことは企業の施策としてよ く見られるが，この企業もアプリ利用による来店・近接 行動にわずかではあるが金額換算が可能なポイントを付 与している。

表 2 では記載していないが, ごく一部に, Monetaryが 非常に低いにも関わらず，来店・近接行動を非常に高頻 度で行っている顧客の存在が確認された。この顧客群は

\begin{tabular}{|c|c|c|c|c|c|c|c|}
\hline \multirow[b]{2}{*}{$\begin{array}{l}\text { Monetary } \\
5 \text { 分位 }\end{array}$} & \multirow[b]{2}{*}{$\begin{array}{l}\text { 顧客 } \\
\text { 比率 }\end{array}$} & \multirow[b]{2}{*}{ Monetary } & \multirow[b]{2}{*}{ Frequency } & \multicolumn{4}{|c|}{ ーエンゲージメント行動- } \\
\hline & & & & $\begin{array}{l}\text { WEB } \\
\text { アクセ久 }\end{array}$ & $\begin{array}{l}\text { 来店近接 } \\
\text { 機能利用 }\end{array}$ & $\begin{array}{l}\text { 祀注文 } \\
\text { 店頭受取 }\end{array}$ & $\begin{array}{c}\text { アプリ起動 } \\
\text { (購買日のみ) }\end{array}$ \\
\hline 1 & $20 \%$ & $70.9 \%$ & $54.1 \%$ & $69.3 \%$ & $82.1 \%$ & $80.1 \%$ & $59.0 \%$ \\
\hline 2 & $20 \%$ & $17.5 \%$ & $23.4 \%$ & $16.9 \%$ & $13.4 \%$ & $13.0 \%$ & $21.4 \%$ \\
\hline 3 & $20 \%$ & $7.5 \%$ & $12.2 \%$ & $7.6 \%$ & $4.1 \%$ & $4.3 \%$ & $10.7 \%$ \\
\hline 4 & $20 \%$ & $3.2 \%$ & $6.7 \%$ & $4.2 \%$ & $0.4 \%$ & $1.8 \%$ & $5.8 \%$ \\
\hline 5 & $20 \%$ & $0.9 \%$ & $3.5 \%$ & $2.1 \%$ & $0.1 \%$ & $0.8 \%$ & $3.1 \%$ \\
\hline
\end{tabular}


ポイント獲得を主目的としている可能性が大きく，この ごく一部の顧客の影響によって，来店・近接行動と購入 金額との相関係数は有意であるものの, これらのエンゲー ジメント行動の中では一番相関が小さい結果となって いる。

この結果からは, エンゲージメント行動は総じていえ ば経営指標に相関をするものの, インセンティブが付与 されている行動についてはポイント獲得などを目的とす るセグメントが発生してしまい，そのごく一部のセグメ ントによって経営指標への相関や回帰が正しいものとな らないことが指摘できる。インセンティブを目的とした エンゲージメント行動と, そうではないエンゲージメン 卜行動を識別することも重要となる。このセグメントの 存在については, シングルソースデータの分析結果でも 再度紹介する。

\section{2. 既存研究の応用 : 優良性の確認}

既存研究からは, マルチチャネル化 (=複数の販売チヤ ネルを利用）した顧客が売上額という面で優良となるの は, 一点当たりの単価や買上げ点数や購入点数などより も，来店回数が増えていることが強い要因であることが 指摘されていた（Matsuda, 2017）。この点が複数の販売 チャネル利用のみならず, 複数のコミュニケーションチャ ネルでも起こるのかを確認するために, WEB サイトへの アクセスと，オムニチャネルを代表する行動であるアプ リ内の来店・近接行動に着目した。

2 つのチャネルへの接触行動の有無から 4 つの群を作 り, 実店舗への来店回数との関連と, そもそも来店回数 が多い顧客が複数のコミュニケーションチャネルを利用 するかを確認した。WEB サイトへのアクセスとアプリ内
の来店・近接機能利用は, それ自体が購入ではなく, エ ンゲージメント行動として考えられる。

表 3 は, Matsuda（2017）に従って, 来店回数の影響 を確認したものである。4つの群の顧客比率, 平均購入 金額, 平均来店回数, 1 来店当たりの平均購入金額, 1 購入当たりの平均購入数量を示しており, 顧客比率以外 は, WEB アクセスと来店・近接行動が「両方なし」の群 を 1 とした数字を記している。

表 3 からは, WEB アクセスとアプリの来店・近接行動 機能を利用した顧客の平均購入金額が高いことがわかり， エンゲージメント行動をした顧客の優良性がここでも確 認できる。さらに右側 3 列からは， 1 来店当たりの購入 金額や, 1 購買当たりの購入数量は, 4 つの群で平均来 店回数ほど変化していないことがわかり, 平均来店回数 が，平均購入金額を押し上げている様子がわかる。この 結果は Matsuda（2017）が購買チャネルで示す結果とほ ぼ同様であるが，複数のコミュニケーションチャネルの 利用でも, 来店回数を上げていることが, 結果として購 買金額の多さに繋がることが確認できた。

続いて, 同じくMatsuda（2017）で指摘されている知 見の応用を試みる。彼の研究では複数の販売チャネルを 使う以前から，来店回数が多い顧客が複数チャネルによ る購入を行って「マルチチャネル化」することを示して いるため, その枠組みに従い, WEB サイトアクセスと来 店・近接行動という 2 つのエンゲージメント行動を行っ た（いわば「オムニ化」した）セグメントは，そのコミュ ニケーションチャネルを使う以前から来店回数が高いの か,を確認した。

図 1 に示す 2 つの折れ線グラフは，4 か月を 1 期間と し，第 1 期目（period 1：「p1」と表現）から第 6 期目ま

\begin{tabular}{cccccc} 
& 顧客比 & $\begin{array}{c}\text { 平均 } \\
\text { 購入金額 }\end{array}$ & $\begin{array}{c}\text { 平均 } \\
\text { 来店回数 }\end{array}$ & $\begin{array}{c}\text { 1 来店当たり } \\
\text { 平均購入金額 }\end{array}$ & $\begin{array}{c}1 \text { 購買当たり } \\
\text { 平均購入数量 }\end{array}$ \\
\hline 両方なし & $86.4 \%$ & 1.00 & 1.00 & 1.00 & 1.00 \\
WEB アクセスのみ & $12.3 \%$ & 2.33 & 1.91 & 1.22 & 1.18 \\
来店・近接行動のみ & $0.1 \%$ & 2.76 & 3.11 & 0.89 & 0.95 \\
両方あり & $1.2 \%$ & 4.19 & 4.06 & 1.03 & 1.08
\end{tabular}


での計 2 年間の期間で，来店回数がどう変化したかを示 したものである。左図が第 3 期目にはじめて, WEB サイ トアクセスもしくは来店・近接行動機能の利用した顧客 の動向を表現している。第 3 期目の WEB サイトアクセ スの有無と来店・近接行動の有無で 4 つのセグメントを 構成し，そのセグメントごとに各期間の平均来店回数を 示している。右図は同じく第 4 期目にはじめてその行動 をしたセグメントを表現している。

図 1 から，コミュニケーションチャネルがマルチチャ ネル化する顧客は，それより以前の期も来店をしている 様子がわかる。また，来店・近接行動だけでは効果が薄 いが, WEB アクセスとの 2 つのコミュニケーションチャ ネルが来店回数に相乗効果をもたらしていること, その 後に来店回数は漸減していくが，事後にも効果をもたら していることも確認できる。この結果も, Matsuda (2017) が販売チャネルで行った結果と類似している。なお，第 2，5，6 期を確認しても，同様の傾向が確認されたこと を付記しておく。

WEB サイトと来店・近接行動というコミュニケーショ ンチャネルでは，常にWEB サイトへのアクセスのほう が, 高い来店回数と関係があるということは, オムニチャ ネル行動もしくはエンゲージメント行動と考えられる 顧客行動の中にも，来店回数により繋がりやすい夕イプ のものがあることが想定できる。Verhoef, Neslin, and Vroomen（2007）が行っているチャネルの属性評価のよ うな研究が, 今後さらに進展していくと考えられるオム ニチャネル的行動にも行われることが望ましいだろう。

\section{V. 実証 3 : 自社の管轄外からみるエンゲージメン 卜行動例}

本節では，課題で確認された，自社の管理下のチャネ ル外の行動を知るために, 特定企業のアプリの前後でど のようなオンライン上での行動が行われているかを探っ た。本節で用いる調査会社のシングルソースデータは, (株) インテージが保有する「i-ssp」である。デー夕期間 は 2016 年前半の半年，エリアは首都圈（一都六県）で ある。このデータには，モバイル（Android 端末のみ） による WEB サイトアクセスと検索語，それに PC によ るWEB サイトアクセスと検索語が取得されており，さ らにモバイルアプリの起動ログも付与されている。人数 は各利用デバイスのデータによって若干の違いがある が，約 5,000 人前後となっている。このデータから，才 ムニチャネル戦略を実践している小売業 2 社が提供する アプリ利用の「前後 10 分間」の他社を含めた利用アプ リやWEB サイトアクセスや情報探索行動を探った。

当該企業のアプリの利用前後 10 分間の行動内訳とし ては，他社を含めたアプリ利用が $76.5 \%$ ，モバイル端末 によるWEB アクセスが $21.6 \%$ ， モバイルでの検索が $1.9 \%$ となっており，圧倒的にアプリ利用が多かったた め，当該小売業のアプリを利用する前後に使っているア プリの傾向を，全体の利用数順位との差によって確認 した。

利用アプリの利用数上位は一般に普及している SNS ア
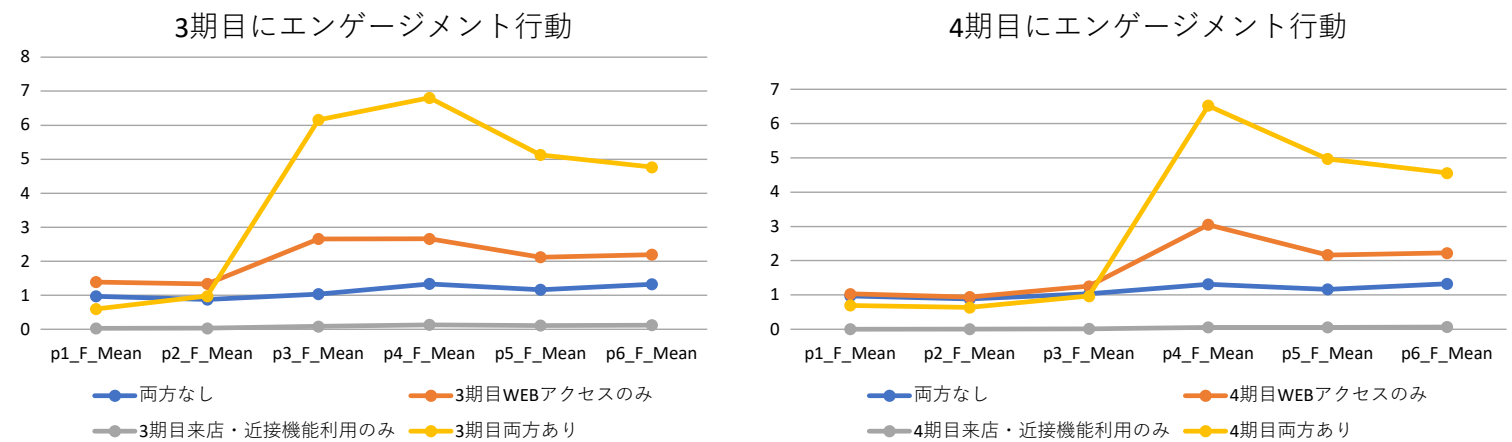
プリやブラウザなどがランクインしたが， 20 位〜 50 位 付近などの順位が落ちたところに明確な違いが確認でき た。それは，その小売業のアプリ以外の「ポイント獲得 用アプリ」が数多くランクインし，数分間などの短い時 間のうちに次々にそのアプリを起動していることがわかっ た。この行動は明らかなポイント・インセンティブ獲得 目的と考えられる。なお，当該アプリの前後に閲覧して いる WEB サイトを確認したところでは, 大手 EC サイ ト, GMS のセール情報, 大手キャリアのポイントサイト など，インセンティブ情報や価格比較，お得情報への情 報感度の高さや，インターネット利用が価格検索に繋が る様子が確認できた。

企業は，他社アプリの起動状況は基本的に捕捉ができ ないため, 自社アプリ利用前後のこうした行動からは, 重要な示唆を得ることができる。金銭などへの換算が可 能なポイント獲得を強い動機として, 他社アプリを次々 に起動してポイント獲得を行う消費者は, その小売企業 目線からは「自社アプリを毎日起動してくれている顧客, 毎日のように来店・近接行動をしてくれている顧客」, つ まりエンゲージメント行動を頻繁に行っている顧客と見 えてしまう。しかし，前述の通り，購入金額ランクが非 常に少ないところにポイント獲得狙いのセグメントが存 在していたように，そうした顧客は自社に売上を多くは もたらさないであろうし，自社に対するロイヤルティが 低い可能性も考えられる。ポイントは引当金計上などで 企業の利益を圧迫しかねないため, どのような人がポイ ント狙いであるかは把握すべきであろう。

なお，消費者による「自社の管理範疇外」の他の行動 例としては, このシングルソースデータに付随するチョ コレートの購入状況から, 情報探索の可能性が高まるバ レンタインデーの前後に期間を絞って情報探索行動と購 入行動の関係を確認した。その結果，「チョコチップマ フィン」といった具体的な検索や，そこから移動したと 考えられるレシピサイトを確認したあとにチョコレート の購入が起こる（例：語句検索をし，レシピサイトをみ た人の約 4 分の 1 以上がその後にチョコレートを購入し ている）といった能動的な情報探索の結果としての購入 や, TVCF でチョコレートの CM に接触をした後の購入 などが確認されたことを付記しておく。

\section{VI. まとめと議論}

本研究は, 仮説検証型ではなく探索型の研究として, オムニチャネル研究における現状の課題を明らかにし， その課題に合わせたデータの提示を行ってきた。

まず現状として，オムニチャネルという言葉が叫ばれ て久しいが, 企業の多くは, 管理可能な自社チャネル内 のシームレスな統合もまだ十分に進んだとはいえない段 階であることを確認した。そして，管理範囲外のチャネ ルにおける消費者や顧客の行動把握, 販売チャネルも伴 うコミュニケーションチャネルや，そのチャネルを介し て表出する行動面のエンゲージメントについての知見が まだ充分に蓄積されていないことを課題として指摘した。 この課題を受け，まずアンケートから，オムニチャネ ルと併せて議論されることの多いショールーミングと WEB ルーミングに焦点を当て, これらの行動を行ってい る顧客は, オムニチャネル戦略を実践する企業への行動 面が高まることを実証 1 で示した。続いて実証 2 では, RFM という頻繁に用いられる既存の顧客の指標とエン ゲージメント行動は強く相関すること，ごく一部である がインセンティブ目的と思われるセグメントが存在する こと, そして, エンゲージメント行動をとる顧客は来店 回数が増えることが優良性の要因であることや，複数の エンゲージメント行動をすることの相乗効果, それより 以前から来店があった顧客がエンゲージメント行動をす る様子などを示した。そして実証 3 では, 自社チャネル 以外の行動把握という目的のため, シングルソースデー 夕から, オムニチャネル戦略を実践する小売業のアプリ を使う前後 10 分間の利用アプリ状況を調べ，ポイント 獲得用アプリを使う一部のセグメントが存在することや, レシピサイト閲覧後の購入が起こっている様子などを示 した。

以上の結果からは, 実店舗を有す小売業としては, オ ムニチャネル戦略のひとつのカギが, 多様なチャネルを 介したコミュニケーションを通じて, 実店舗への来店を 促進させることにあると指摘できる。ツール利用におい てインセンティブ獲得を設けている場合は, そのインセ ンティブのみを狙う層にはアプローチをしないことも検 
討すべきだろう。

本論では考慮, 議論できていない関連テーマや要因も 多い。コロナ禍を踏まえた消費行動の変化や, キャッシュ レス決済やポイントの連携，仮想現実 $(\mathrm{VR}) \cdot$ 拡張現実 (AR), Beacon などでの通信といった新しいテクノロジー などのテーマは議論ができていない。オムニチャネルに 大きくかかわる組織要因, 小売企業の出店チャネルの出 自の違い（実店舗が先か, EC が先か, 等), 大きな影響 が考えられる SNS 利用なども今回の議論対象ではない。 しかし, 今後新しいチャネルや顧客行動の把握が出てき たとしても，本研究のアプローチを応用し，例えば実証 2 で取り上げた，過去にどのような行動をした顧客が新 チャネルを利用し，その相乗効果や持続効果はどこまで 続くのか, といった形を, その新しいチャネルに適用で きる。

オムニチャネルはバズワードなどともいわれることも あり, DX (Digital Transformation) や D2C (Direct to Customer) などの表現で語られるテーマと重なる部分も あるが，顧客とのやり取りが各種チャネルを通じてなさ れるという面は今後変わることはなく，まだ発展途上， 普及の初期段階である。アプリが有す機能の進化から顧 客理解も促進されるであろうし, コロナ禍においてはオ ンライン接客などの, 今まではあまりなかった顧客に接 する方法も行われつつある。今後もテクノロジーの進化 などによって顧客の把握は深まり，顧客へのアプローチ 方法も広がっていくだろう。しかしいくつかのチャネル を介して顧客とやり取りを交わしていくという基本は変 わらないため, 時代に合わせつつも，これまでの知見を 応用した顧客の理解を蓄積していくことが, 今後も求め られる。

\section{謝辞}

本研究は, 公益財団法人吉田秀雄記念事業財団の平成 29 年度第 51 次研究助成を受けて実施したものである。 財団関係者の皆様，またデー夕を提供頂いた企業ご担当 者様に,ここに記して厚く御礼申し上げます。

注

1）インターネットでの注文を店舗で受け取った場合は店舗の
成果とするが, 各チャネルの適性な評価をするために, 社 内評価に扔いて, その売上同額を $\mathrm{EC}$ 部隊の評価としてダ ブルカウントする方法。当時（株）キタムラでオムニ チャネルを先導した逸見光次郎氏の提唱とされる。(参照 : ECzine Editorial Depertment (Eds.). (2017).)

2） Lemon and Verhoef（2016）は, 顧客経験を捉えるタッチポ イントとして 4 つの類型を提示している。自社で管理が可 能なチャネルである「ブランド・オウンド」タッチポイン 卜，パートナーと提携することでアクセスが可能となる 「パートナー・オウンド」タッチポイント, 消費者や顧客が 有す「カスタマー・オウンド」タッチポイント, そして, それ以外の「ソーシャル・外部・独立」の夕ッチポイント である。後の 2 つは企業側からの管理が基本的に難しい。

\section{References}

Blattberg, R. C., Kim, B. D., \& Neslin, S. A. (2008). Why database marketing? In Database marketing (pp. 13-46). New York: Springer.

Cross Marketing Inc. (2014). Showrooming ni kansuru chousa. Cross Marketing Inc. Retrieved from https://www.crossm.co.jp/news/release/20141015/ (October 20, 2017). (クロス • マーケティング社 (2014)。「ショールーミングに関する調 査」『クロス・マーケティング社』) (In Japanese)

ECzine Editorial Depertment (Eds.). (2017). ECzine ureru EC site no sugoi shikake. Tokyo: Shoeisha. (ECzine 編集部（編著） (2017).『ECzine 売れる EC サイトのすごい仕掛け』翔泳 社) (In Japanese)

Garcia, K. (2018). US Omnichannel Retail StatPack 2018. New York: eMarketer.

Gulati, R., \& Garino, J. (2000). Get the right mix of bricks \& clicks. Harvard Business Review, 78(3), 107-114.

Kakui, R. (2015). Omni-channel strategies. Tokyo: Nikkei Publishing Inc. (角井亮一 (2015).『オムニチャネル戦略』 日本経済新聞出版社) (In Japanese)

Kondo, K. (2015). Multiplication of channels and multichannel integration in retailing. Journal of Economics \& Business Administration, 212(1), 61-73. (近藤公彦 (2015).「小売業 におけるマルチチャネル化とチャネル統合」『国民経済雑 誌』212(1), 61-73) (In Japanese)

Kondo, K. (2018). Characteristics of Japanese type of omnichannel and its theoretical issues. Journal of Marketing \& Distribution, 21(1), 77-89.（近藤公彦 (2018).「日本型オムニチャネルの 特質と理論的課題」『流通研究』21(1), 77-89) (In Japanese)

Kotler, P., Kartajaya, H., \& Setiawan, I. (2016). Marketing 4.0: Moving from traditional to digital. Hoboken, NJ: Wiley.

Kumar, V., \& Venkatesan, R. (2005). Who are the multichannel shoppers and how do they perform? Correlates of multichannel shopping behavior. Journal of Interactive Marketing, 19(2), 44-62. doi: 10.1002/dir.20034

Lemon, K. N., \& Verhoef, P. C. (2016). Understanding customer experience throughout the customer journey. Journal of Marketing, 80(6), 69-96. doi: 10.1509/jm.15.0420

Matsuda, Y. (2017). How to analyze multi-channel customers are multi-channel customers excellent? Direct Marketing Review, 
16, 4-17.（松田芳雄（2017）.「マルチチャネル顧客の分析 方法一マルチチャネル顧客は優良か一」『Direct Marketing Review』16,4-17) (In Japanese)

Neslin, S. A., Grewal, D., Leghorn, R., Shankar, V., Teerling, M. L., Jacquelyn, S. T., \& Verhoef, P. C. (2006). Challenges and opportunities in multichannel customer management. Journal of Service Research, 9(2), 95-112. doi: 10.1177/ 1094670506293559

Nishihara, A. (2019). Syouhisyakoudou no shintenkai 2. Kokyaku engagement: Kigyou to kokyaku tono kankeisei ni okeru aratana shiten. In N. Mitsuro (Ed.). Psychology of consumer behavior improving relationship between consumer and company (pp. 175-193). Kyoto: Kitaoojishobo.（西原彰宏 (2019).「消 費者行動の新展開 2 : 顧客エンゲージメント一企業と顧客 との関係性における新たな視点一」永野光朗（編）『消費者 行動の心理学: 消費者と企業のよりよい関係性（産業・組織 心理学講座 第 5 巻) 』pp. 175-193, 北大路書房) (In Japanese)

Okutani, T. (2016). Omnichannel ka suru consumer to consumer decision process: Mobile device ga motarasu retaling no mirai to kadai. Japan Marketing Journal, 36(2), 21-43. doi: 10.7222/ marketing.2016.039 (奥谷孝司（2016）。「オムニチャネル化 する消費者と購買意思決定プロセス一Mobile Device がもた らす小売業の未来と課題一」『季刊マーケティングジャーナ ル』36(2), 21-43) (In Japanese)

Osera, S. (2015). Understanding of multichannel customer management a review. Journal of business administration Keiei Ronshu, 85, 197-209. (大瀬良伸（2015）。「マルチチャネル 顧客マネジメントの理解一マルチチャネル研究のレビュー 一」『経営論集』85, 197-209) (In Japanese)

Rapp, A., Baker, T. L., Bachrach, D. G., Ogilvie, J., \& Beitelspacher, L. S. (2015). Perceived customer showrooming behavior and the effect on retail salesperson self-efficacy and performance. Journal of Retailing, 91(2), 358-369. doi: 10.1016/j.jretai. 2014.12.007

Rudy, K. (1985). Jissen direct marketing senryaku: Nippon no chokuhan seikou manual. Tokyo: Business Sha. (ルデイー和子 (1985)。『実践ダイレクトマーケティング戦略一日本の直販 成功マニュアル』ビジネス社) (In Japanese)

Verhoef, P. C., Neslin, S. A., \& Vroomen, B. (2007). Multichannel customer management: Understanding the research-shopper phenomenon. International Journal of Research in Marketing, 24(2), 129-148. doi: 10.1016/j.ijresmar.2006.11.002

Verhoef, P. C., Kannan, P. K., \& Inman, J. J. (2015). From multichannel retailing to omni-channel retailing, introduction to the special issue on multi-channel retailing. Journal of Retailing, 91(2), 174-181. doi: 10.1016/j.jretai.2015.02.005

Yamamoto, S. (2015). Aspects of omnichannel and consumer behavior. Business \& Accounting Review, 16, 55-68. (山本昭二 (2015).「オムニチャネルの特性と消費者行動」『ビジネス \&アカウンティングレビュー』16,55-68) (In Japanese)

\section{太宰潮（だざいうしお）}

2001 年学習院大学経済学部卒業後, (株) 富士総合研究所 を経て, 2005 年学習院大学大学院経営学研究科博士前期課 程修了。

2008 年, 同博士後期課程単位取得退学後, 現大学 - 専任講 師を経て現職。

専門は消費者行動論, プライシング, 価格戦略等

\section{西原 彰宏（にしはら あきひろ）}

2007 年関西学院大学商学部卒業後, 2009 年関西学院大学大 学院商学研究科修士課程修了。

2012 年同博士後期課程単位取得満期退学後, 2013 年同博士 (商学) 取得, 亜細亜大学経営学部専任講師を経て現職。 専門はマーケティング・マネジメント, 消費者行動論

\section{奥谷 孝司（おくたにたかし）}

一橋大学大学院経営管理研究科博士後期課程在学中 米ワシントン州州立ワシントン大学 (University of Washington）卒業後, 人材派遣会社勤務を経て, 1997 年株 式会社良品計画入社。店舗勤務, 商品開発, WEB 事業を経 験。2 010 年早稲田大学大学院商学研究科修士課程修了。 2015 年 10 月旧オイシックス株式会社（現 オイシックス・ ラ・大地）入社。

執行役員，Chief Omni-Channel Officer。 2018 年 9 月 株式会社顧客時間創業 共同 CEO 取締役

\section{鶴見 裕之（つるみ ひろゆき）}

2007 年立教大学大学院社会学研究科博士課程後期課程修 了 博士 (社会学)

公益財団法人流通経済研究所主任研究員を経て, 2010 年よ り横浜国立大学大学院国際社会科学研究院准教授, 2020 年 より現職。

専門はマーケティング，マーケティング・サイエンス 